Plant Biosystems - An International Journal Dealing with all Aspects of Plant Biology

Official Journal of the Societa Botanica Italiana

\title{
Bioclimatic analysis in a region of southern Italy (Calabria)
}

\section{T. Caloiero, G. Callegari, N. Cantasano, V. Coletta, G. Pellicone \& A. Veltri}

To cite this article: T. Caloiero, G. Callegari, N. Cantasano, V. Coletta, G. Pellicone \& A. Veltri (2016) Bioclimatic analysis in a region of southern Italy (Calabria), Plant Biosystems - An International Journal Dealing with all Aspects of Plant Biology, 150:6, 1282-1295, DOI: 10.1080/11263504.2015.1037814

To link to this article: http://dx.doi.org/10.1080/11263504.2015.1037814

Accepted author version posted online: 08 Apr 2015.

Published online: 07 May 2015.

Submit your article to this journal $\pi$

山 Article views: 36

Q View related articles $₫$

View Crossmark data $₫$

Citing articles: 1 View citing articles 


\title{
ORIGINAL ARTICLE
}

\section{Bioclimatic analysis in a region of southern Italy (Calabria)}

\author{
T. CALOIERO, G. CALlEGARI, N. CANTASANO, V. COLETTA, G. PELliCONE, \\ \& A. VELTRI
}

Institute for Agricultural and Forest Systems in the Mediterranean (ISAFOM), National Research Council of Italy (CNR), Via Cavour 4/6, 87036 Rende (CS), Italy

\begin{abstract}
In this study, an analysis of precipitation and temperature data has been performed over 67 series observed in a region of southern Italy (Calabria). At first, to detect possible trends in the time series, an analysis was performed with the MannKendall non-parametric test applied at monthly and seasonal scale. An additional investigation, useful for checking the climate change effects on vegetation, has also been included analysing bioclimatic indicators. In particular, Emberger, RivasMartinez and De Martonne indices were calculated by using monthly temperature and precipitation data in the period 1916-2010. The spatial pattern of the indices has been evaluated and, in order to link the vegetation and the indices, different indices maps have been intersected with the land cover data, given by the Corine Land Cover map. Moreover, the temporal evolution of the indices and of the vegetation has been analysed. Results suggest that climate change may be responsible for the forest cover change, but, given also the good relationship between the various types of bioclimate and forest formations, human activities must be considered.
\end{abstract}

Keywords: Bioclimatic indices, vegetation distribution, precipitation, temperature, trend analysis, southern Italy

\section{Introduction}

The notion of climate, as one of the leading environmental factors governing the distribution of plants and vegetation, has long been recognized (Von Humboldt \& Bonpland 1807; Grisebach 1838). The importance of climate studies through its main features, such as temperature, precipitation and evapotranspiration and their interactions, has been indicated in different vegetation or plant geography surveys (Tuhkanen 1980; Box 1981; Walter 1985; Woodward 1987; Prentice 1990). In order to quantify and determine the influence of climate on plants and vegetation, simple variables can be used. However, it has been pointed out that these variables alone do not give enough information and their combination in the form of climatic indices is considered to be useful (De Martonne 1926; Tuhkanen 1980).

The Mediterranean region lies in a transition zone between the arid climate of North Africa and the Temperate and rainy climate of Central Europe and it is affected by interactions between mid-latitude and tropical processes. Because of these features, even relatively minor modifications of the general circulation, e.g. shifts in the location of mid-latitude storm tracks or sub-tropical high pressure cells, can lead to substantial changes in the Mediterranean climate (Giorgi \& Lionello 2008). This condition makes the Mediterranean area a potentially vulnerable region to climatic changes as induced, for example, by increasing concentrations of greenhouse gases (e.g. Lionello et al. 2006; Ulbrich et al. 2006). The Mediterranean climate is characterized by mild, rainy winters and warm, dry summers. These special and unique climatic conditions have great influence on natural physical processes, including soil formation, ecological features, landform development and karst topography as well as human activities (Efe 2005; Atalay 2006; Efe \& Greenwood 2007; Kaniewski et al. 2007). Although plant species and communities differ between regions, the dominant vegetation, in the Mediterranean basin, is evergreen woodland with evergreen sclerophyllous shrubs and trees like carob

Correspondence: T. Caloiero, Institute for Agricultural and Forest Systems in the Mediterranean (ISAFOM), National Research Council of Italy (CNR), Via Cavour 4/6, 87036 Rende (CS), Italy. Tel: +390984 841464. Fax: +390984 841497. Email: tommaso.caloiero@isafom.cnr.it 
tree (Ceratonia siliqua Linnaeus), cork oak (Quercus suber Linnaeus), holm oak (Quercus ilex Linnaeus), mastic tree (Pistacia lentiscus Linnaeus), kermes oak (Quercus coccifera Linnaeus) and fodder shrub (Medicago arborea Linnaeus). These species are resistant to summer droughts, have deep rooting systems and a high resprouting capacity.

In the Mediterranean Basin, there have been numerous phytogeographical studies based on the analysis of climatic parameters and many bioclimatic indices have been formulated (De Martonne 1926; Emberger 1930; De Philippis 1937; Rivas-Martınez 1993, 1996).

In Italy, the first phytoclimatic assessment, planned by De Philippis (1937) within national boundaries, used some specific climatic variables, based on precipitation and temperature data, for the study of forest vegetation. At the same time, De Philippis (1937) created a detailed kind of classification, based on the same abiotic parameters, which highlighted a clear zonation of terrestrial vegetation differentiated in Lauretum, Castanetum, Fagetum, Picetum and Alpinetum. In the last decades, the phytoclimatic knowledge is rapidly improved using some new climatic indices suggested by Thornthwaite and Mather (1957), Montero De Burgos and Gonzalez Rebollar (1974) and RivasMartınez (1993). Blasi (1996) characterized the Italian bioclimate by considering 390 thermopluviometric stations distributed along the Italian peninsula. In particular, using monthly mean temperatures and precipitation and through a principal component analysis, 26 climatic types (with subtypes) have been defined. This work has been upgraded by Blasi and Michetti (2005) which identified the phytoclimatic region distribution in Italy (Mediterranean, Temperate, Transitional Mediterranean and Transitional Temperate phytoclimatic regions) and evaluated a phytoclimatic map of Italy with 28 types of phytoclimate. At regional scale, the phytoclimatic studies were performed in some regions, such as Sardinia (Arrigoni 1968), Tuscany (Arrigoni 1973), Umbria (Venanzoni et al. 1996), Lazio (Blasi 1994), Campania (Iovino \& Menguzzato 1991), Apulia (Forte \& Vita 1998), Basilicata (Cantore et al. 1988) and Sicily (Terzi et al. 2006).

In Calabria, the first analysis on bioclimatic patterns and on geographic distribution of forest vegetation types was carried out by Ciancio (1971). This study, based on the traditional phytoclimatic classification by Pavari, distinguished four bioclimatic areas covering the following regional areas in percentage terms: Lauretum hot subtype (52.5\%), Lauretum medium-cold subtype (26.5\%), Castanetum $(10.7 \%)$ and Fagetum (10.3\%). Pellicone et al. (2014) updated the analysis of Ciancio (1971) using both new variables and new data for the period
1972-2010 and subdivided the region into three main belts: Lauretum, $74.4 \%$ of the area (cold $9.0 \%$, medium $29.0 \%$ and warm $36.4 \%$ ); Castanetum, $15.2 \%$ of the surface (cold $10.3 \%$ and warm $4.9 \%$ ); Fagetum, $10.4 \%$ of the area (cold $1.2 \%$ and warm $9.2 \%)$. In the analysis of the Italian bioclimate, Blasi (1996) evaluated that the Temperate and the Transitional Temperate regions are distributed all along the Italian peninsula reaching Calabria. In particular, a typical Mediterranean climate has been detected in the lower areas of the region, while a Temperate one has been evaluated for the higher areas (over $1100 \mathrm{~m}$ a.s.1.).

Phytoclimatic studies sometimes include indices given by the combination of simple climate parameters such as the mean annual temperature or precipitation. Other times, these surveys may also involve radiation, wind speed, light hours, altitude, latitude, etc. Different studies highlight changes in precipitation and temperature spatial-temporal behaviour, especially in the Mediterranean basin. In particular, several researches have been carried out to investigate trends in annual and seasonal precipitation, at a large scale (Kutiel et al. 1996; Piervitali et al. 1998; Xoplaki et al. 2006), and for entire nations or regions (Esteban-Parra et al. 1998; De Luis et al. 2000; Feidas et al. 2007; Río et al. 2011). Long precipitation records have been investigated in northern and central Italy (Montanari et al. 1996; Demichele et al. 1998; Brunetti et al. 2006b), in southern Italy (Palmieri et al. 1991; Brunetti et al. 2004; Brunetti et al. 2006a; Samui et al. 2011b) and, particularly, in the Calabria Region (Coscarelli et al. 2004; Buttafuoco et al. 2011a, 2011b; Caloiero et al. 2011a; Brunetti et al. 2012; Ferrari et al. 2013; Caloiero et al. 2014; Sirangelo et al. 2015). With respect to the temperature, the majority of these studies have been conducted at large spatial scale (Easterling et al. 2000; Klein Tank \& Können 2003; Vose et al. 2004; Vincent et al. 2005) or at national spatial scale (Domonkos \& Tar 2003; Brunetti et al. 2006a), while few studies have been made at local scale (Brunetti et al. 2004; Piccarreta et al. 2004; Buttafuoco et al. 2010; Caloiero et al. 2014).

This research aims at analysing the relationship between climate change and forest cover in the Calabria Region (southern Italy). With this aim, a study of precipitation and temperature trends in the Region was performed. Then, the same data-set has been used for the investigation of some of the most common bioclimatic indices and, in order to link the vegetation and the indices, the indices maps have been intersected with land cover data. Finally, the temporal evolution of the indices and of the vegetation have been analysed in order to verify if changes in forest cover can be linked to climatic changes. 


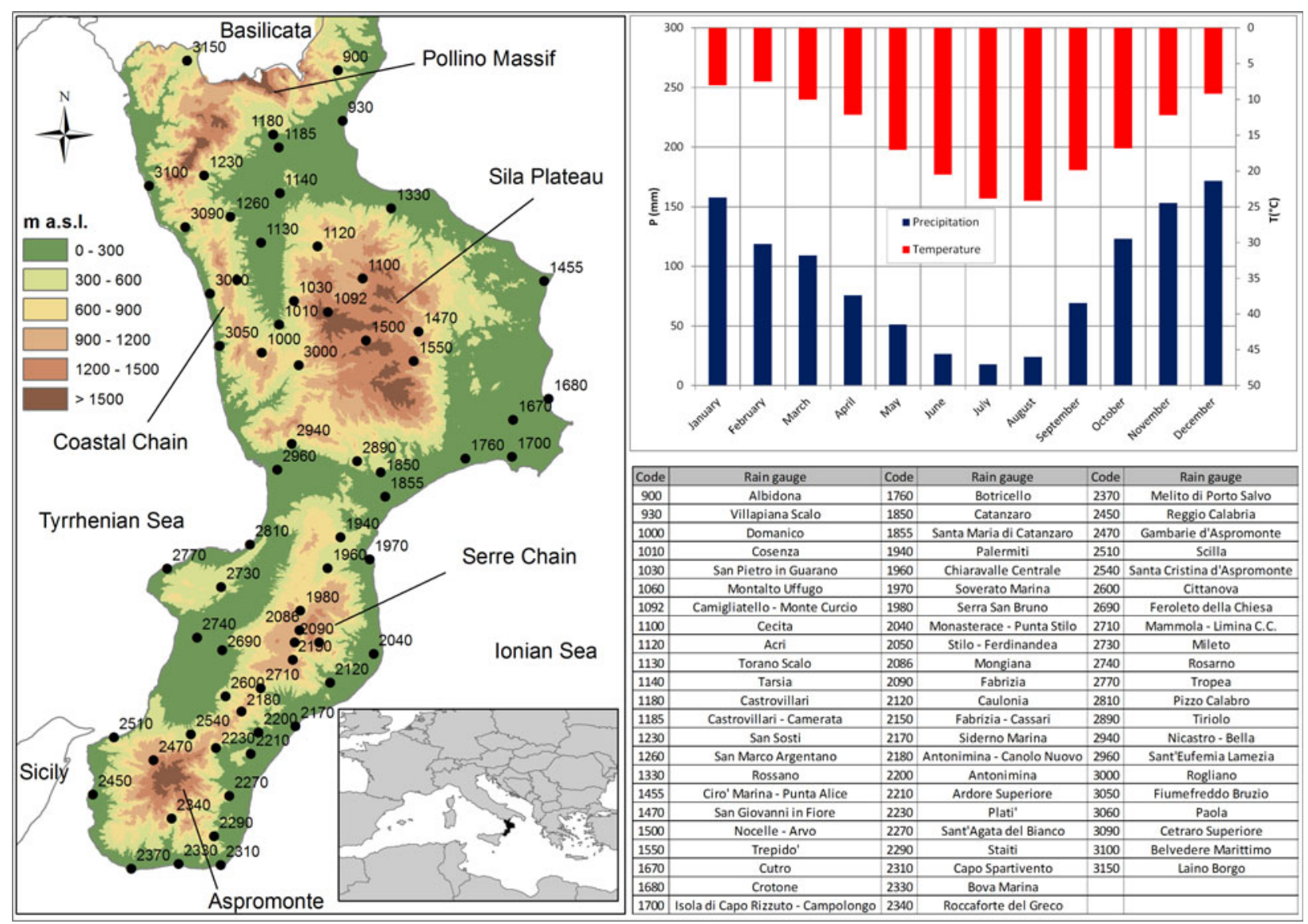

Figure 1. Digital elevation model of the study area including the location and the description of the stations with mean monthly rainfall and temperature values in the Calabria Region.

\section{Study area and data}

The Calabria Region is a peninsula of $15,080 \mathrm{~km}^{2}$, with an oblong shape that occupies the southern part of Italy (Figure 1). Although in Calabria high summits are not frequent, it is one of the most mountainous regions in Italy. Because of its geographic position and its mountainous nature, Calabria has a high climatic variability with a typically subtropical dry summer, also known as the Mediterranean climate. In summer, the influence of the Azores anticyclone supports a rather dry and Temperate weather, while breeze circulations develop on the coast and inland (Buttafuoco et al. 2011a). In the other seasons, Mediterranean cyclogenesis affects the regional climate. Forest distribution reflects the small-scale variability of climate and shows that typical plants associations and exclusive taxonomic entities are frequent over the territory. In general, four fundamental vegetation layers can be identified, according to Pavari's (1916) classification. The first layer, named Lauretum belt, is composed of Mediterranean maquis with Mediterranean pines (i.e. Pinus haleppensis Miller) from sea level to about $400 \mathrm{~m}$ a.s.l. and by oak mixed forests (Quercus ilex Linnaeus, Cupressus Linnaeus,
Quercus suber Linnaeus and Quercus pubescens Willdenow) with Mediterranean pines up to $800 \mathrm{~m}$ a.s.l. The second layer, named Castanetum belt, is composed by chestnut (Castanea Miller), Italian oak (Quercus Linnaeus), maple (Acer Linnaeus) and alder (Alnus Miller) from 800 to $1200 \mathrm{~m}$ a.s.l., while beech - silver fir (Fagus sylvatica Linnaeus - Abies alba Miller), turkey oak - calabrian pine (Quercus cerris Linnaeus - Pinus laricio Poiret) mixed forests and pure formations of turkey oak (Quercus cerris Linnaeus), beech (Fagus sylvatica Linnaeus), silver fir (Abies alba Miller) and calabrian pine (Pinus laricio, Poiret), up to $1660 \mathrm{~m}$ a.s.1., belong to the third layer (warm sub-zone of Fagetum belt). The upper side of Fagetum belt with continuous forest cover (cold subzone) extends over about $1.4 \%$ of total forest area and it comprises high quote species (Pinus laricio Poiret, Fagus sylvatica Linnaeus and Pinus leucodermis Antoine), standing on higher mountain reliefs of the Region (Sila plateau, Aspromonte, Pollino massif). The fourth layer, named Picetum belt, comprises a small distribution of high altitude forest species (Pinus leucodermis Antoine and Fagus sylvatica Linnaeus) which constitute sparse groups on the peak of Pollino massif. 
The monthly and annual rainfall and temperature data-sets used in this work have been selected from the original rain gauge network of Centro Funzionale Multirischi of Calabria Region, which consisted of 311 stations, with a density of one station per $48 \mathrm{~km}^{2}$. Taking into account the missing data in the series within the period 1916-2010, ultimately 67 rainfall and temperature series were selected, with an average density of one station per $225 \mathrm{~km}^{2}$ (Figure 1).

\section{Methodology}

Initially, a trend analysis was performed in order to detect the temporal behaviour of rainfall and temperature in Calabria, using the well-known rank-based non-parametric Mann-Kendall test (Mann 1945; Kendall 1962). Then, a measure of the precipitation effectiveness or aridity of the region calculated from precipitation and temperature has been carried out by evaluating some bioclimatic indices. Moreover, in order to characterize the spatial pattern of these indices, their values have been spatially distributed and, in the attempt to link vegetation types and climatic indices, different maps have been intersected with the Corine Land Cover (CLC) map (Figure 2). Thus, it has been possible to cross the different forest types, with the bioclimatic classes of the different indices used, and to define the related forest surfaces belonging to the different classes. This approach yielded useful data concerning the distribution of forest vegetation in relation to the different bioclimatic indices throughout the region. Finally, in order to assess the impact of climate change on forest cover in Calabria, the temporal evolution of vegetation was also analysed. This is an important issue, in fact land-use cover changes have been widely studied worldwide (e.g. Houghton 1994; Ojima et al. 1994; Lambin et al. 2003; Brown et al. 2005; Lepers et al. 2005), in the Mediterranean basin (e.g. Ales et al. 1992; GarcíaRuiz et al. 1996; Debussche et al. 1999; MacDonald et al. 2000; Santos 2000) and also in Italy (Falcucci et al. 2007; Marchetti et al. 2014). In particular, Marchetti et al. (2014) in the past 20 years highlighted a marked increase in the forest surface and, at the same time, a considerable reduction in agricultural area.

In this study, all the spatial procedures were performed using Esri ArcGIS 9.3.1.

\section{Emberger classification}

Emberger (1930) classified the Mediterranean climate on the basis of three important climatic parameters: precipitation, temperature and evaporation. The precipitation $(P)$ is represented by the annual precipitation $(\mathrm{mm})$. For temperature, the mean of the maximum temperatures of the hottest month in the year $(M)$ and the mean of the minimum temperatures of the coldest month in the year $(m)$ were considered because vegetation growth is strictly related to these thermal limits. The temperature parameter is represented by the quotient $(M / 2+m / 2)$. Evaporation is represented by the temperature range $(M-m)$ because evaporation frequently increases with it; this parameter expresses the continentality of a climate. All these climatic parameters are represented in the pluviothermic quotient of Emberger, given by the following formula in which the temperature values are expressed in absolute degrees (K):

$$
Q=\frac{1000 \cdot P}{((M+m) / 2) \cdot(M-m)}=\frac{2000 \cdot P}{M^{2}-m^{2}} .
$$

Generally speaking, the Mediterranean climate is more arid when the quotient is smaller (Table I). An improvement in the Mediterranean climate classification was made utilising both the $Q$ and the minimum temperature of the coldest month. In fact, this last parameter expresses, in a generic and useful way, the degree and the duration of the critical frost period: the lower the temperature of the coldest month, the more severe these conditions are. These two parameters are graphically represented in a climatogram, a chart where on the $y$ - and $x$-axes the temperature of the coldest month and the quotient values are, respectively, represented.

\section{De Martonne index}

The De Martonne index (1926) is calculated using the mean annual precipitation $(P$ in $\mathrm{mm})$ and the mean annual temperature $\left(t\right.$ in $\left.{ }^{\circ} \mathrm{C}\right)$. The basis of De Martonne's formula gives an index of aridity $\left(I_{\mathrm{a}}\right)$ which is expressed in the formula:

$$
I_{\mathrm{a}}=\frac{P}{t+10}
$$

Higher $I_{\mathrm{a}}$ values indicate humid conditions while lower indicate aridity conditions (Table II).

\section{Rivas-Martinez index}

Rivas-Martinez (1996) proposed a more general classification of the climate. Five macrobioclimates have been identified: Tropical, Mediterranean, Temperate, Boreal and Polar. In this case it is important to determine the boundary between the Mediterranean and Temperate macrobioclimates both present in the study area. The procedure involves the use of the Ombrothermic index of the 


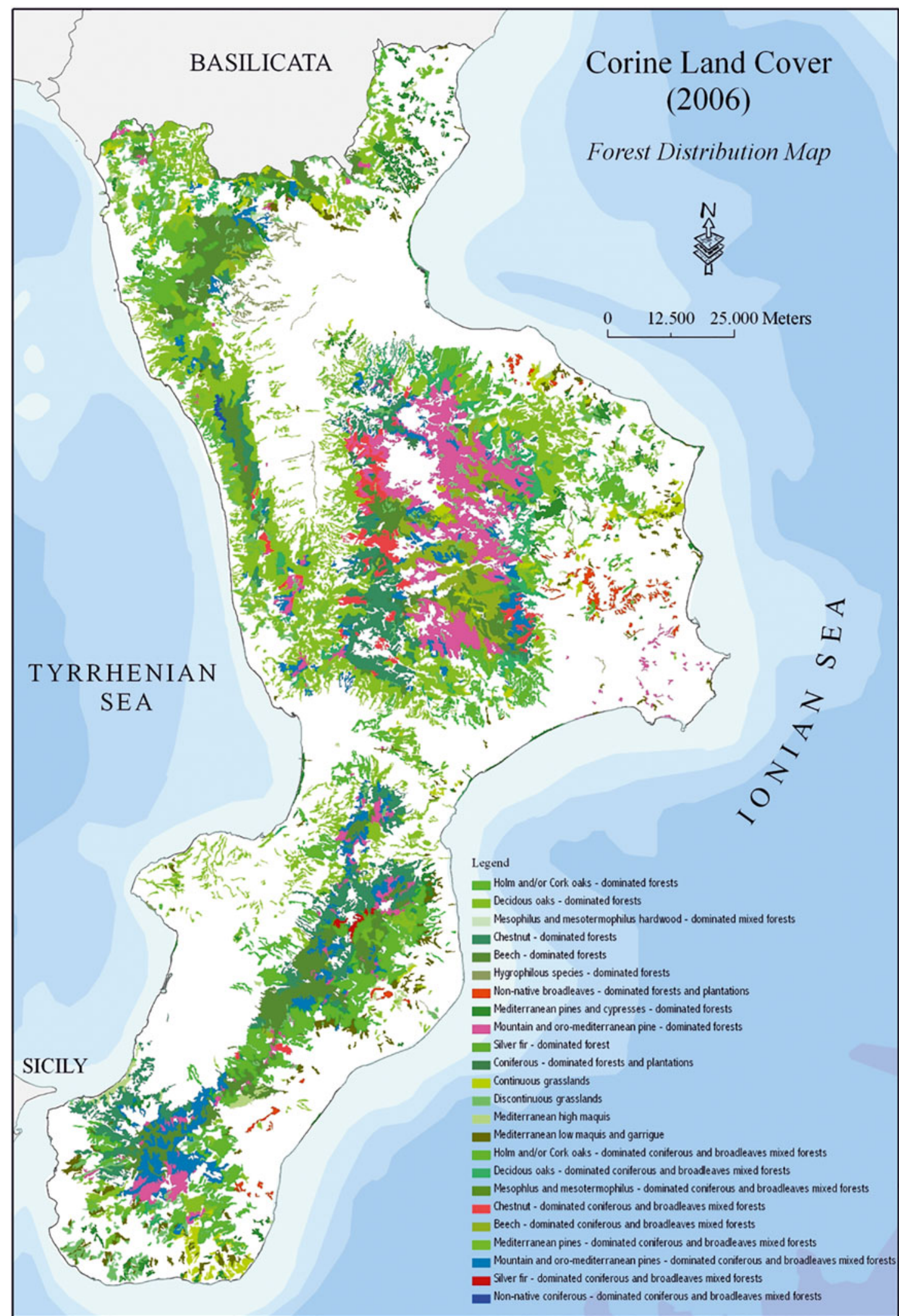

Figure 2. Forest distribution map of Calabria Region according to CLC (2006). 
Table I. Climatic classification according to Emberger (1930).

\begin{tabular}{ll}
\hline$Q$ & Climate type \\
\hline Over 150 & Hyper-humid \\
$98-150$ & Humid \\
$57-98$ & Sub-humid \\
$30-57$ & Semi-arid \\
$17-30$ & Arid \\
$0-17$ & Hyper-arid \\
\hline
\end{tabular}

summer period $\left(I_{\mathrm{ov}}\right)$.

$$
I_{\mathrm{ov}}=\frac{\sum P_{\mathrm{Jun}}+P_{\mathrm{Jul}}+P_{\mathrm{Aug}}}{\sum T_{\mathrm{Jun}}+T_{\mathrm{Jul}}+T_{\mathrm{Aug}}} .
$$

If $I_{\mathrm{ov}}<1.5$, then the macrobioclimate is Mediterranean; if $I_{\mathrm{ov}}>2$, then the macrobioclimate is Temperate; if $1.5<I_{\mathrm{ov}}<2$, then it is a transition area that can be further assigned to a specific macrobioclimate by calculating the summer compensated ombrothermic index $\left(I_{\mathrm{ovc}}\right)$ :

$$
I_{\mathrm{ovc}}=\frac{\sum P_{\mathrm{May}}+P_{\mathrm{Jun}}+P_{\mathrm{Jul}}+P_{\mathrm{Aug}}}{\sum T_{\mathrm{May}}+T_{\mathrm{Jun}}+T_{\mathrm{Jul}}+T_{\mathrm{Aug}}}
$$

\section{Results and discussion}

The results of the application of the trend analysis to the monthly and seasonal series of precipitation are shown in Figure 3. With regards to the monthly total precipitation, a general negative trend, although not significant for the whole region, was detected for the period 1916-2010, in particular for the autumn and winter periods (Figure 3(a)). In fact, $84.8 \%$ and $69.2 \%$ of the rain gauges show a negative trend $50.0 \%$ and $15.4 \%$ significant at $95 \%$ of significant level) in winter and autumn, respectively. On a monthly basis, a negative and significant trend was detected in January and November, with, respectively, $34.8 \%$ and $46.9 \%$ of the rain gauges, showing a negative trend at the $95 \%$ significance level. Conversely, summer precipitation shows a positive trend, particularly in July and August in which significant trends were detected in $30.8 \%$ and $23.1 \%$ of the rain

Table II. Climatic classification according to De Martonne (1926).

\begin{tabular}{ll}
\hline$I_{\mathrm{a}}$ & Climate type \\
\hline Over 60 & Hyper-humid \\
$30-60$ & Humid \\
$20-30$ & Sub-humid \\
$15-20$ & Semi-arid \\
$5-15$ & Arid \\
$0-5$ & Hyper-arid \\
\hline
\end{tabular}

gauges, respectively. A significant negative trend has also been found in February $(24.6 \%$ of the rain gauges) while a significant positive trend has been also found in September (43.9\% of the rain gauges).

In Figure 3(b)-(d), the results of the trend analysis based on the temperature series are shown. In particular, the average temperature (Figure 3(b)) shows a remarkable and positive trend in the spring and summer period, from April to August, with significant trend ranging between $30.8 \%$ and $50.8 \%$ of the temperature series. A clear negative trend has been detected in September and November, significant for $32.3 \%$ and $17.5 \%$ of the temperature series, respectively. On a seasonal scale, results show a positive trend in spring and summer periods with percentages of significant trend of $32.3 \%$ and $42.2 \%$, respectively, while in autumn a meaningful and negative trend for $19.0 \%$ of the stations has been detected.

The maximum temperature (Figure 3(c)) shows a clear upward trend of temperatures both on a monthly and on a seasonal scale, although not significant for many stations. Only in the months of September and October there is the prevalence of a negative trend, significant for $45.3 \%$ and $12.5 \%$ of the stations, respectively. At seasonal scale, a clear tendency to positive trends in maximum temperatures has been shown, in particular in spring and summer periods, with important percentages ranging from $26.2 \%$ for spring to $30.8 \%$ of the stations for the summer.

For the minimum temperature (Figure 3(d)) a positive trend for almost all the months has been observed, with significant percentages ranging from $15.9 \%$ of the stations in February to $60.9 \%$ in July. Only the months of September and November show a statistically significant negative trend $(15.4 \%$ of the stations for both). At seasonal scale, a positive trend has been shown in spring and in summer $(38.5 \%$ and $53.1 \%$ of the stations, respectively).

Results showed a clear change in trend, either in rainfall or in temperature, in the Calabria Region for the period 1916-2010. Due to the rainfall and temperature changes, in order to investigate the climatic characteristics of Calabria Region, a number of indices were estimated for the whole observation period. In particular, the Emberger, Rivas-Martinez and De Martonne indices were calculated. With regards to the Emberger classification and in particular to the climatogram, five different climates can be identified in the Calabria Region (Figure 4). Most thermopluviometric stations, analysed in this work, fall within semi-arid (28.0\%) and sub-humid $(28.0 \%)$ classes, with hot and very hot conditions. Approximately, $20.0 \%$ of the stations belong to the hyper-humid class, with Temperate (11.9\%), cool $(7.5 \%)$ and cold $(1.5 \%)$ conditions. In particular, 
(a)

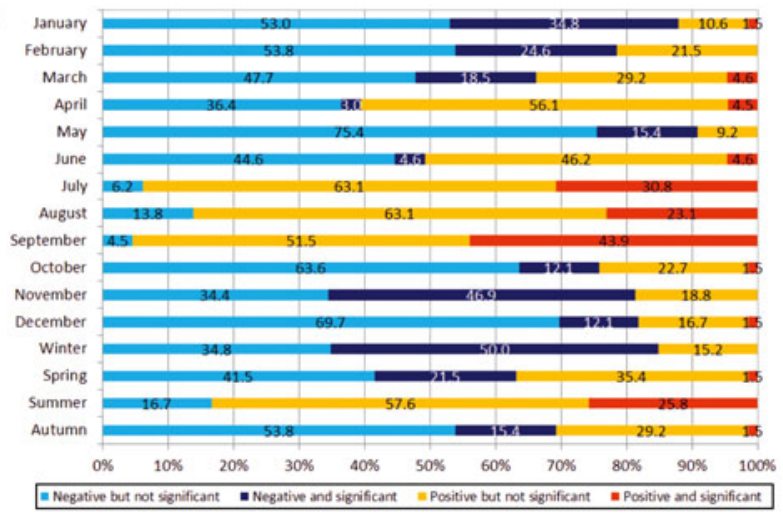

(c)

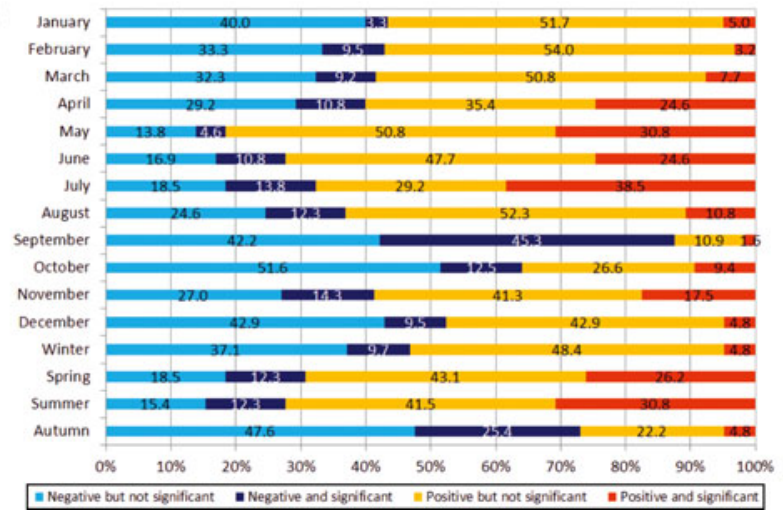

(b)

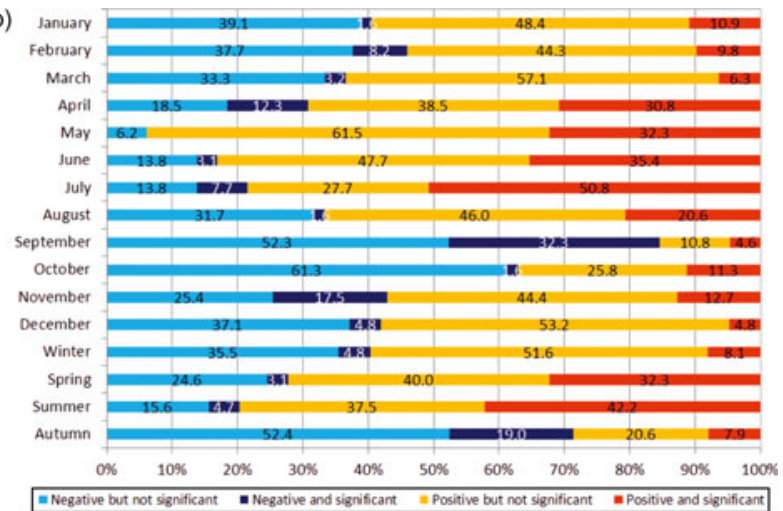

(d)

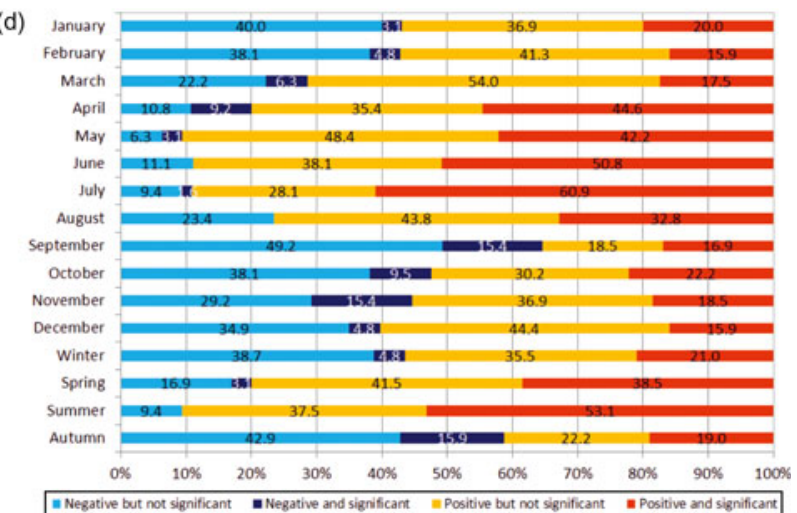

Figure 3. Percentages of series presenting positive or negative (significant or not significant) trends for various time aggregations for (a) rainfall; (b) average temperature; (c) maximum temperature; (d) minimum temperature.

this last state has been evidenced only in the Camigliatello - Monte Curcio (code: 1092, $1730 \mathrm{~m}$ a.s.1.) station, one of the highest of the Region. Finally, only two stations show arid conditions, Villapiana (code: 930, $5 \mathrm{~m}$ a.s.1.), on the northeastern side of the Region, and Melito di Porto Salvo (code: $2370,7 \mathrm{~m}$ a.s.1.), in the extreme southern part of the Region, with hot and very hot winter, respectively.
The results obtained from the analysis of RivasMartinez index, according with Blasi and Michetti (2005), indicated that most of the rain gauges are located in the Mediterranean region (76.0\%) while the remaining part $(24.0 \%)$ in the Temperate one (Figure 5(a)). Thus, the Mediterranean and the Temperate regions represent two phytogeographic units, distinct but complementary to each other determining the distribution of tree species. The

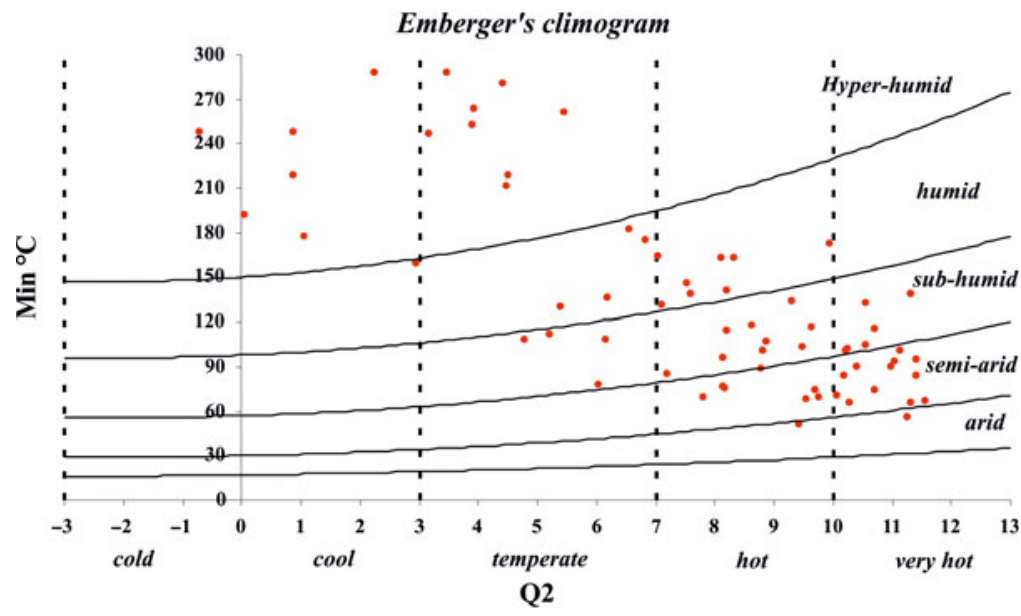

Figure 4. Climate conditions according to Emberger classification. On the $y$-and $x$-axes, the temperatures of the coldest month and the quotient values are, respectively, represented. 

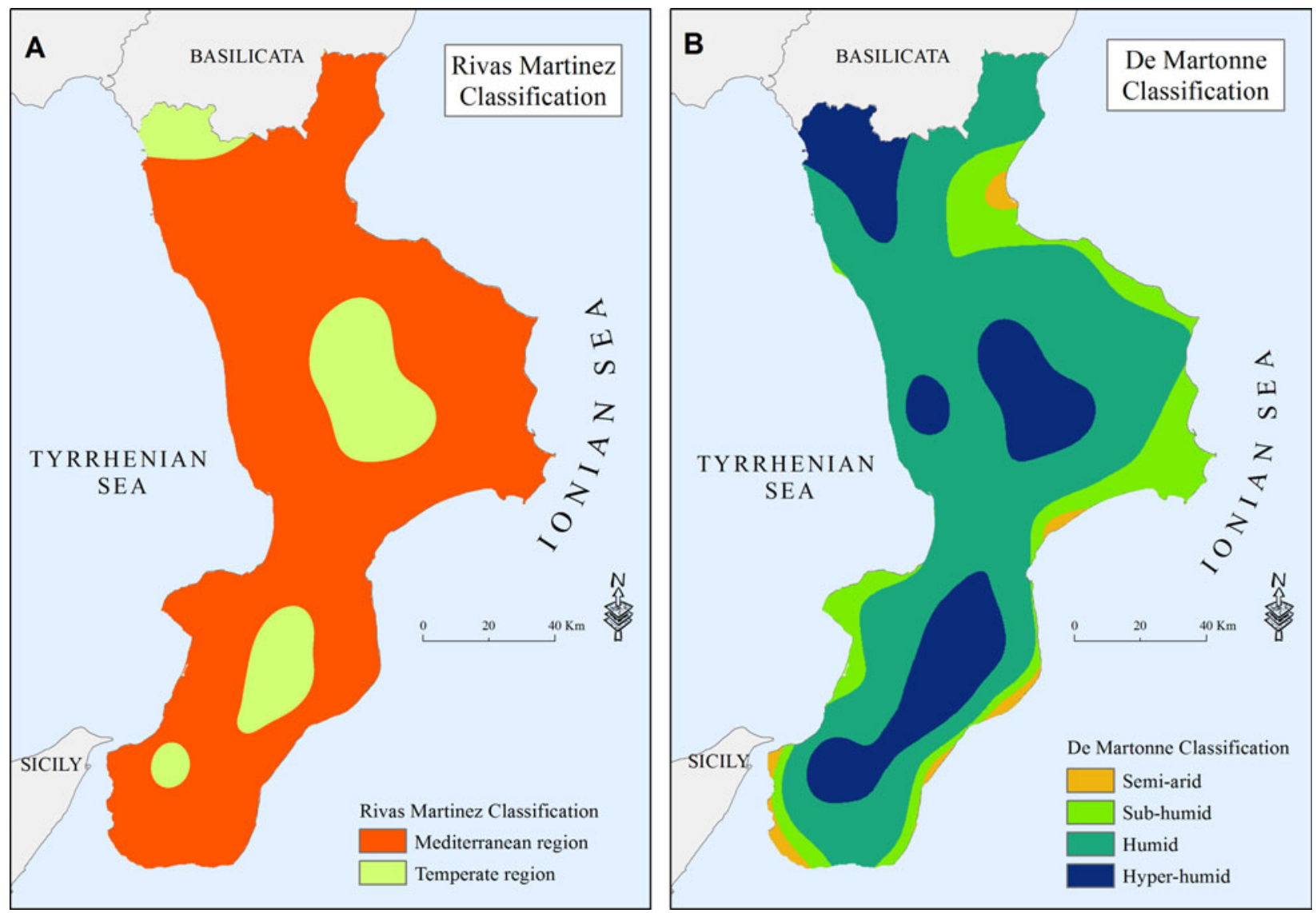

Figure 5. Rivas-Martinez (a) and De Martonne (b) classification maps for Calabria Region.

Mediterranean region, located from sea level up to an altitude of $800-850 \mathrm{~m}$ a.s.l. extends from the coastal areas to the lower slopes of the region while the Temperate region, located at $900 \mathrm{~m}$ a.s.1., occupies the mountain areas within the region.

The overlay between the CLC and Rivas Martinez maps (Table III and Figure 6(a)) shows that the Mediterranean region is characterized by the dominant presence of two large consortia plants: the maquis shrubland and the basal plane forest with most types of forest categories of Calabria entirely falling within this region. These forests consist mainly in hygrophilous species, such as willows (Salix Linnaeus), poplars (Populus Linnaeus) and alders (Alnus Miller) with mixed forests of conifers and deciduous trees. Predominantly, chestnut (Castanea Miller) and beech (Fagus Linnaeus) forests also fall within the Mediterranean region, respectively, for $72.0 \%$ and $56.0 \%$ of their extension, as well as the forests of holm oaks (Quercus ilex Linnaeus) and cork oaks (Quercus suber Linnaeus) (79\%) and the formations of mainly deciduous oaks $(91.0 \%)$. As expected, forests of Mediterranean pines fall within the Mediterranean region $(94.0 \%)$.

In this region, there is a good matching of the typical Mediterranean floristic contingent, consisting of chestnut and oak trees with the Mediterranean climate of the study area, as evidenced by numerous authors (e.g. Quézel \& Médail 2002).

Silver fir (Abies alba Miller), mountain pine (Pinus nigra Arnold, Pinus laricio Poiret and Pinus leucodermis Antoine) and Douglas fir (Pseudotsuga menziesii Mirb. Franco) forests are located in the Temperate region for $79.0 \%, 57.0 \%$ and $79.0 \%$, respectively. The majority of mixed forests, consisting mainly of deciduous trees, fall within the Temperate region, respectively, for $57.0 \%$ and $86.0 \%$ of their area as well as the coniferous and broadleaves mixed forests with predominance of beech which, for $86.0 \%$, fall within the Temperate region. In particular, silver fir (Abies alba Miller), black pine (Pinus nigra Arnold) and loricate pine (Pinus leucodermis Antoine) forests have been found in the area of Serre chain, in most Sila Plateau and in the highest parts of the Pollino Massif, respectively.

The De Martonne index sub-divides Calabria into four regions, corresponding to the semi-arid, sub-humid, humid and hyper-humid classes (Figure 5(b)). In total, $3.0 \%$ of the area, in the Ionian side of the region, lies within the semi-arid category. Moreover, $14.0 \%$ of the regional territory falls within the sub-humid class and is located along the Ionian coast and in the southern side of 
Table III. Results of the overlay between the CLC and indices maps: percentage of forest (according to the CLC, 2006) falling within the different index classes.

\begin{tabular}{|c|c|c|c|c|c|c|c|}
\hline \multirow[b]{2}{*}{ CLC code } & \multirow[b]{2}{*}{ Type of forest } & \multicolumn{4}{|c|}{ De Martonne } & \multicolumn{2}{|c|}{ Rivas Martinez } \\
\hline & & Semi-arid & Sub-humid & Humid & Hyper-humid & Mediterranean & Temperate \\
\hline 324 & $\begin{array}{l}\text { Mediterranean low maquis and garrigue } \\
\text { Silver-fir and/or Norway spruce dominated }\end{array}$ & 1 & 9 & 63 & 28 & 84 & 15 \\
\hline 3123 & forests & - & - & - & 100 & 21 & 79 \\
\hline 3114 & Chestnut-dominated forests & - & 1 & 66 & 34 & 72 & 28 \\
\hline 3115 & $\begin{array}{l}\text { Beech-dominated forests } \\
\text { Holm and/or Cork oaks-dominated }\end{array}$ & - & - & 25 & 75 & 56 & 44 \\
\hline 3111 & $\begin{array}{l}\text { coniferous and broadleaves mixed forests } \\
\text { Mediterranean pines and cypresses- }\end{array}$ & - & - & 62 & 38 & 79 & 20 \\
\hline 3121 & $\begin{array}{l}\text { dominated forests } \\
\text { Mountain and oro-Mediterranean pines- } \\
\text { dominated coniferous and broadleaves }\end{array}$ & 3 & 21 & 67 & 8 & 94 & 6 \\
\hline 3122 & $\begin{array}{l}\text { forests } \\
\text { Decidous oaks-dominated broadleaves }\end{array}$ & - & 2 & 47 & 50 & 43 & 57 \\
\hline 3112 & forests & - & 3 & 77 & 20 & 91 & 9 \\
\hline 3116 & $\begin{array}{l}\text { Hygrophilous species-dominated forests } \\
\text { Non-native coniferous-dominated coniferous }\end{array}$ & 1 & 4 & 78 & 17 & 100 & - \\
\hline 3125 & $\begin{array}{l}\text { forests and plantations } \\
\text { Non-native broadleaves-dominated forests }\end{array}$ & - & - & 98 & 2 & 21 & 79 \\
\hline 3117 & $\begin{array}{l}\text { and plantations } \\
\text { Mesophilous and mesothermophilous }\end{array}$ & - & 16 & 81 & 3 & 99 & 1 \\
\hline 3113 & $\begin{array}{l}\text { hardwood-dominated mixed forests } \\
\text { Silver-fir and/or Norway spruce-dominated }\end{array}$ & - & - & 33 & 67 & 63 & 37 \\
\hline 31323 & $\begin{array}{l}\text { coniferous and broadleaves mixed forests } \\
\text { Chestnut-dominated coniferous and }\end{array}$ & - & - & - & 100 & 18 & 82 \\
\hline 31314 & $\begin{array}{l}\text { broadleaves mixed forests } \\
\text { Non-native conifer-dominated coniferous }\end{array}$ & - & - & 58 & 42 & 43 & 57 \\
\hline 31325 & $\begin{array}{l}\text { and broadleaves mixed forests } \\
\text { Beech-dominated coniferous and broadleaves }\end{array}$ & - & - & 100 & - & 100 & - \\
\hline 31315 & $\begin{array}{l}\text { mixed forests } \\
\text { Mesophilous and mesothermophilous } \\
\text { hardwood-dominated coniferous and }\end{array}$ & - & - & 21 & 79 & 14 & 86 \\
\hline 31313 & $\begin{array}{l}\text { broadleaves mixed forests } \\
\text { Holm and/or Cork oaks-dominated }\end{array}$ & - & - & - & 100 & 100 & - \\
\hline 31311 & $\begin{array}{l}\text { coniferous and broadleaves mixed forests } \\
\text { Mediterranean pines-dominated coniferous }\end{array}$ & - & - & 23 & 77 & 57 & 43 \\
\hline 31321 & $\begin{array}{l}\text { and broadleaves mixed forests } \\
\text { Mountain and oro-Mediterranean pines- } \\
\text { dominated coniferous and broadleaves }\end{array}$ & - & 12 & 74 & 14 & 94 & 6 \\
\hline 31322 & $\begin{array}{l}\text { mixed forests } \\
\text { Decidous oaks-dominated coniferous and }\end{array}$ & - & - & 35 & 65 & 63 & 37 \\
\hline 31312 & broadleaves mixed forests & - & - & 81 & 19 & 87 & 13 \\
\hline
\end{tabular}

Tyrrhenian coast. At last, $60.0 \%$ of the region can be classified as humid and occupies almost all the region with the exception of the coast and of the main reliefs which lie, as $23.0 \%$ of the regional area, in the hyperhumid class.

The overlay map between the CLC and De Martonne map (Table III and Figure 6(b)) shows that $3.0 \%$ of the Mediterranean pines forests fall within the semi-arid class, $21.0 \%$ falls in the subhumid one, $67.0 \%$ in the wet class and $8.0 \%$ in the hyper-humid one. While in the semi-arid class only Mediterranean pine forests fall, in the sub-humid one there are $12.0 \%$ of coniferous and broadleaves mixed forests, with predominance of Mediterranean pines and low percentages of deciduous oaks and hygrophilous species. Most of forests fall within the humid and hyper-humid classes. In particular, the silver fir (Abies alba Miller) forests and the formations, mainly consisting of mesophilous and mesothermophilous broadleaves, entirely fall within the hyper-humid class while almost all of the Douglas fir Pseudotsuga menziesii (Mirb.) Franco forests fall within the humid one.

Due to the rainfall and temperature changes, with the aim to evaluate the temporal evolution of the indices, three sub-periods of 30 years each, 19211950, 1951-1980 and 1981-2010, have been considered. For each sub-period both the Rivas- 

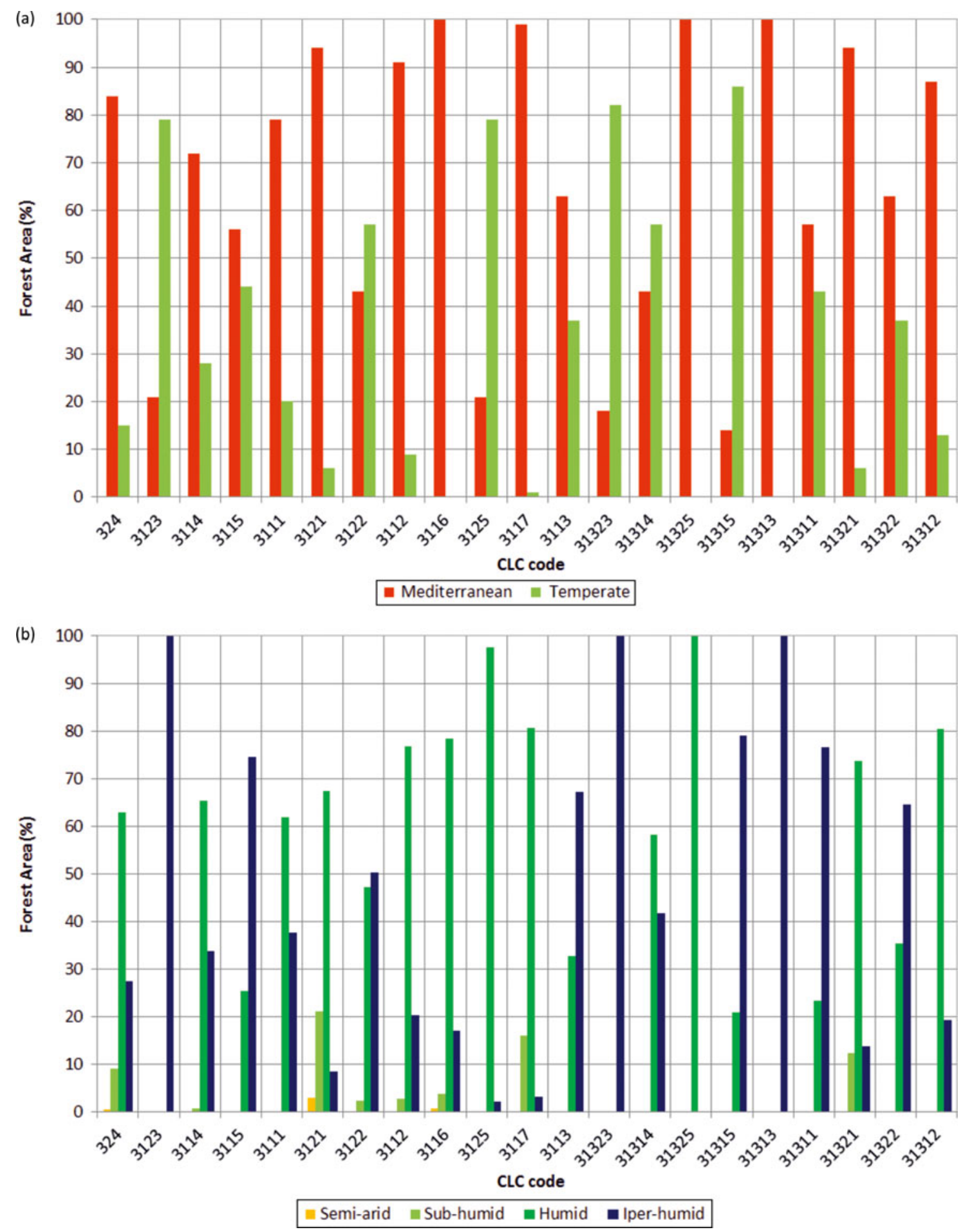

Figure 6. Results of the overlay between the CLC and the indices maps. On the $x$-and $y$-axes, the forest code (according to the CLC, 2006) and the percentage of forest falling within the different index classes have been, respectively, represented.

Martinez and the De Martonne indices have been calculated and mapped and the percentage of regional area, falling within the different indices classes, has been evaluated (Table IV). As a result, considering the Rivas-Martinez index, an increase of the areas affected by Mediterranean climate and a consequent reduction of the areas affected by
Temperate climate has been detected. As regards the De Martonne index, a tendency through subhumid conditions emerged. In fact, while the semiarid and hyper-humid classes showed a clear reduction, a slightly increase of the humid class and, above all, a marked increase of the sub-humid one have been evaluated. 
1292 T. Caloiero et al.

Table IV. Percentage of regional area falling within the different index classes for three different subperiod of 30 years.

\begin{tabular}{llcrr}
\hline Index & Class & $1921-1950$ & $1951-1980$ & $1981-2010$ \\
\hline Rivas-Martinez & Temperate & 18.3 & 15.4 & 15.1 \\
& Mediterranean & 81.7 & 84.6 & 84.9 \\
De Martonne & Semi-arid & 4.9 & 6.7 & 1.3 \\
& Sub-humid & 8.9 & 8.7 & 67.9 \\
& Humid & 66.3 & 16.8 & 89.9 \\
\hline
\end{tabular}

In order to assess the potential relationship between climate change and forest cover in Calabria, also the temporal evolution of the vegetation was also analysed. In Calabria, an increase of forested area was recorded from 1800 to 1954 (from 184,000 to 397,000 ha), even if between 1940 and 1950 a decrease of 30 ha occurred (Cassa per il Mezzogiorno 1957). In 1950s the Calabria Region was the fifth most wooded Italian region, with a forested area of 375,000 ha and a coefficient of woodland density of $26.0 \%$. In particular, high forests constituted $61.0 \%$ of the total regional woody area $(12.0 \%$ conifers, $46.0 \%$ broadleaves, $3.0 \%$ mixed conifers and broadleaves), while coppice forests constituted $39.0 \%$ (20.0\% simple coppice system, $19.0 \%$ mixed coppice system). Laricio pine (Pinus laricio Poiret) was the dominant species in coniferous forests, whereas chestnut (Castanea sativa Miller), beech (Fagus sylvatica Linnaeus) and oaks (Quercus spp.) dominated the broadleaved forests (Cassa per il Mezzogiorno 1957).

After the Second World War, a new afforestation project was carried out (Regione Calabria 2007), and Calabria forest area increased by $32 \%$ between 1960 and 1980 (Iovino 1998). Afforestation mainly concerned inland areas of Presila, Serre and Aspromonte, which were more affected by hydrogeological risk. In the last 40 years, mountain area has been re-colonized by forests while uncontrolled urban development led to a reduction of green areas in the valleys. Besides, after the recovery of humid areas, most of coastal territory has undergone a strong anthropic pressure. Nonetheless, a strongly increasing trend in forested area has occurred in the Region between 1970 and 1990. From the analysis of the distribution of forests along elevation zones it results that $66.7 \%$ of forests are located at higher elevations while $28.3 \%$ of these forests are within national parks. Finally, it is noteworthy that most of forested area has arisen by semi-natural processes. In particular, silvicultural activities gave rise to $48.7 \%$ of forests in Calabria (Regione Calabria 2007). From the analysis of land use by CLC, available for 1990 and 2006, a reduction of 3900 ha of forest area has been detected. In particular, coniferous forests with mixed coniferous underwent a 3100-ha decrease, while broadleaves forests were reduced by 800 ha.

These results may be linked to the climate change actually in progress, supporting the hypothesis that when extreme values of indices decrease, the development of natural conifer stands is not supported, whereas agro-forest stands and crop and forest cultivations show a steady and/or increasing trend. However, as highlighted by other authors (e.g. Piovesan et al. 2010), the reduction in precipitation during the winter is not a limiting factor for forest vegetation, especially if accompanied by an increase in summer rainfall, as for the Calabria Region. Climate change and extreme climatic parameters, e.g., the drought that affected the Calabria Region at the beginning of this century (Buttafuoco \& Caloiero 2014; Buttafuoco et al. 2015), could be responsible for the forest cover change, but, given also the good correlation between the various types of bioclimate and forest formations, human activities must be considered. In fact, in the last years, the Calabria Region has been affected by numerous fires, in particular during the summer period and, different from the past, political action has been lacking with respect to afforestation management.

\section{Conclusion}

This paper analyses the temporal behaviour of annual and monthly precipitation and temperature in a region of southern Italy (Calabria) and its possible influence on the regional land cover through the analysis of some bioclimatic indices. In fact, Calabria, due to its geographical position and for its geomorphological and climatic peculiarities, presents a considerable diversification in terms of vegetation, which also is confirmed from a bioclimatic point of view. Results show a reduction in winter-autumn rainfall, an increase in summer precipitation, a rise of the average temperature, mainly due to an increase of the minimum temperature in late spring and summer and a decrease in the autumn-winter period, mainly due to a reduction in the maximum temperature. These results could confirm the hypothesis of a climate change actually in progress. With regards to the Emberger classification and, in particular, to the 
climatogram, five different climates can be identified in the Calabria Region with a predominance of semiarid and sub-humid classes with hot and very hot conditions. According to previous studies (e.g. Blasi \& Michetti 2005), the Rivas-Martinez index indicates that most of the rain gauges are located in the Mediterranean region $(76.0 \%)$ while the remaining part $(24.0 \%)$ in the Temperate one. Moreover, the De Martonne index divides Calabria into four regions, corresponding to the semi-arid, subhumid, humid and hyper-humid classes with $60.0 \%$ of the region which can be classified as humid. The temporal analysis of the Rivas-Martinez and the De Martonne indices in three sub-periods of 30 years showed that Temperate and hyper-humid areas decreased in time while Mediterranean and subhumid areas increased. At the same time, the comparison of the land use between 1990 and 2006 evidenced a reduction of forest area and, above all, a large decrease of coniferous forests. These results may be linked to the climate change actually in progress, but, given also the good relationship between the various types of bioclimate and the forest formations, human activities must also be taken into account.

\section{References}

Ales RF, Martin A, Ortega F, Ales EE. 1992. Recent changes in landscape structure and function in a Mediterranean region of SW Spain (1950-1984). Landsc Ecol 7(1): 3-18. doi:10. 1007/BF02573953.

Arrigoni PV. 1968. Fitoclimatologia della Sardegna [Phytoclimatology of Sardinia]. Webbia 23(1): 1-100. doi:10.1080/ 00837792.1968.10669879.

Arrigoni PV. 1973. Ricerche fitoclimatiche sulla Toscana a sud dell'Arno [Phytoclimatic research in Tuscany, south of the Arno river]. Atti Soc Tosc Sci Nat Mem Ser B 79: 97-106.

Atalay I. 2006. The effects of mountainous areas on biodiversity: A case study from the northern Anatolian mountains and the Taurus mountains. Grazer Schriften der Geographie und Raumforschung 41: 17-26.

Blasi C. 1994. Fitoclimatologia del Lazio [Phytoclimatology of Lazio]. Fitosociologia 27: 151-175.

Blasi C. 1996. Ii Fitoclima d'Italia [The Phytoclimate of Italy]. Giornale Botanico Italiano 130(1): 166-176. doi:10.1080/ 11263509609439523.

Blasi C, Michetti L. 2005. Biodiversità e clima [Biodiversity and climate]. In: Blasi C, Boitani L, La Posta S, Manes F, Marchetti $M$, editors. Stato della Biodiversità in Italia. Contributo alla Strategia Nazionale per la biodiversità. MATTM, Direzione per la Protezione della Natura, SBI. Roma: Palombi Editori. pp. 57-66.

Box EO. 1981. Predicting physiognomic vegetation types with climate variables. Vegetatio 45(2): 127-139. doi:10.1007/ BF00119222.

Brown DG, Johnson KM, Loveland TR, Theobald DM. 2005. Rural land-use trends in the conterminous United States, 1950-2000. Ecol Appl 15(6): 1851-1863. doi:10.1890/035220.

Brunetti M, Buffoni L, Mangianti F, Maugeri M, Nanni T. 2004. Temperature, precipitation and extreme events during the last century in Italy. Global Planet Change 40(1-2): 141-149. doi:10.1016/S0921-8181(03)00104-8.

Brunetti M, Maugeri M, Monti F, Nanni T. 2006a. Temperature and precipitation variability in Italy in the last two centuries from homogenised instrumental time series. Int J Climatol 26(3): 345-381. doi:10.1002/joc. 1251.

Brunetti M, Nanni T, Maugeri M, Auer I, Boehm R, Schoener W. 2006b. Precipitation variability and changes in the Greater Alpine region over the 1800-2003 period. J Geophys Res 111, D11107.

Brunetti M, Caloiero T, Coscarelli R, Gullà G, Nanni T, Simolo C. 2012. Precipitation variability and change in the Calabria region (Italy) from a high resolution daily dataset. Int J Climatol 32(1): 57-73. doi:10.1002/joc.2233.

Buttafuoco G, Caloiero T. 2014. Drought events at different timescales in southern Italy (Calabria). J Maps 10(4): 529-537. doi:10.1080/17445647.2014.891267.

Buttafuoco G, Caloiero T, Coscarelli R. 2010. Spatial uncertainty assessment in modelling reference evapotranspiration at regional scale. Hydrol Earth Syst Sci 14(11): 2319-2327. doi:10.5194/hess-14-2319-2010.

Buttafuoco G, Caloiero T, Coscarelli R. 2011a. Spatial and temporal patterns of the mean annual precipitation at decadal time scale in southern Italy (Calabria region). Theor Appl Climatol 105(3-4): 431-444. doi:10.1007/s00704-011-03988.

Buttafuoco G, Caloiero T, Coscarelli R. 2011b. Spatial patterns of variability for rain fields at different timescales: An application in southern Italy. European Water 36: 3-13.

Buttafuoco G, Caloiero T, Coscarelli R. 2015. Analyses of drought events in Calabria (southern Italy) using standardized precipitation index. Water Resour Manage 29(2): 557-573. doi:10.1007/s11269-014-0842-5.

Caloiero T, Buttafuoco G, Coscarelli R, Ferrari E. 2014. Spatial and temporal characterization of climate at regional scale using homogenous monthly precipitation and air temperature data: An application in southern Italy (Calabria Region). Hydrol Res. doi:10.2166/nh.2014.022.

Caloiero T, Coscarelli R, Ferrari E, Mancini M. 2011a. Trend detection of annual and seasonal rainfall in Calabria (Southern Italy). Int J Climatol 31(1): 44-56. doi:10.1002/joc. 2055.

Cantore V, Iovino F, Pontecorvo G. 1988. Aspetti climatici e zone fitoclimatiche della Basilicata [Climatic aspects and Phytoclimatic areas of Basilicata]. Pubblicazione n. 2. Cosenza: CNR, Istituto di Ecologia e Idrologia Forestale.

Cassa per il Mezzogiorno. 1957. Piano regolatore di massima per la Calabria [Unitary Development Plans of the Calabria region]. Roma: Cassa per il Mezzogiorno.

Ciancio O. 1971. Sul clima e sulla distribuzione altimetrica della vegetazione forestale in Calabria [Climate and distribution of forest in Calabria]. Annali dell'Istituto Sperimentale per la Selvicoltura 2: 323-372.

Coscarelli R, Gaudio R, Caloiero T. 2004. Climatic trends: An investigation for a Calabrian basin (southern Italy). In: Rodda JC, Ubertini L, editors. The basis of civilization. Water science?, IAHS Publ. 286. Wallingford, UK: IAHS Press. pp. 255-266.

Debussche M, Lepart J, Dervieux A. 1999. Mediterranean landscape changes: Evidence from old postcards. Glob Ecol Biogeogr 8(1): 3-15. doi:10.1046/j.1365-2699.1999.00316.x.

De Luis M, Raventos J, Gonzalez-Hidalgo JC, Sanchez JR, Cortina J. 2000. Spatial analysis of rainfall trends in the region of Valencia (east Spain). Int J Climatol 20(12): 1451-1469. doi:10.1002/1097-0088(200010)20:12<1451::AID-JOC547> 3.0.CO;2-0.

De Martonne E. 1926. Une nouvelle function climatologique: L'indice d'aridité [A new climatological function: The Aridity Index]. La Meteorologie 2: 449-458. 
De Michele C, Montanari A, Rosso R. 1998. The effects of nonstationarity on the evaluation of critical design storms. Water Sci Technol 37(11): 187-193. doi:10.1016/S0273-1223(98) 00332-1.

De Philippis A. 1937. Classificazioni ed indici del clima, in rapporto alla vegetazione forestale Italiana [Classification and climatic indices according to the Italian forest distribution]. Nuovo Giornale Botanico Italiano 44(1): 1-169. doi:10.1080/ 11263503709438750.

Domonkos P, Tar K. 2003. Long-term changes in observed temperature and precipitation series 1901-1998 from Hungary and their relations to larger scale changes. Theor Appl Climatol 75(3-4): 131-147. doi:10.1007/s00704-0020716-2.

Easterling DR, Evans JL, Groisman PYA, Karl TR, Kunkel KE, Ambenje P. 2000. Observed variability and trends in extreme climate events: A brief review. Bull Am Meteor Soc 81(3): 417-425. doi:10.1175/1520-0477(2000)081<0417:OVATIE $>2.3 . \mathrm{CO} ; 2$

Efe R. 2005. Land degradation in Taurus mountains (Southern Turkey). Geophys Res Abstr 7: 00922.

Efe R, Greenwood M. 2007. Vegetation zonation patterns on the Goksu Delta (southern Turkey). J Appl Sci 7(16): 2277-2284. doi:10.3923/jas.2007.2277.2284.

Emberger L. 1930. La végétation de la Région Méditerranéenne essai d'une classification des gronpenments végétaux [The vegetation of the Mediterranean region. An effort for the classification of plant communities]. Revue Génerale de Botanique 42: 641-662.

Esteban-Parra MJ, Rodrigo FS, Castro-Diez Y. 1998. Spatial and temporal patterns of precipitation in Spain for the period 1880-1992. Int J Climatol 18(14): 1557-1574: doi:10.1002/ (SICI) 1097-0088(19981130) 18:14<1557::AID-JOC328>3. $0 . \mathrm{CO} ; 2-\mathrm{J}$

Falcucci A, Maiorano L, Boitani L. 2007. Changes in land-use/ land-cover patterns in Italy and their implications for biodiversity conservation. Landscape Ecol 22(4): 617-631. doi:10.1007/s10980-006-9056-4.

Feidas H, Noulopoulou C, Makrogiannis T, Bora-Senta E. 2007. Trend analysis of precipitation time series in Greece and their relationship with circulation using surface and satellite data: 1955-2001. Theor Appl Climatol 87(1-4): 155-177. doi:10. 1007/s00704-006-0200-5.

Ferrari E, Caloiero T, Coscarelli R. 2013. Influence of the North Atlantic oscillation on winter rainfall in Calabria (southern Italy). Theor Appl Climatol 114(3-4): 479-494. doi:10.1007/ s00704-013-0856-6.

Forte L, Vita F. 1998. I Diagrammi Bioclimatici di Montero de Burgos e Gonzalez Rebollar: applicazione al territorio pugliese [The bioclimatic diagrams according to Montero de Burgos and Gonzalez Rebollar: an application in the Apulia region]. Annali della Facoltà di Agraria Dell'università di Bari 35: 45-91.

García-Ruiz JM, Lasanta T, Ruiz-Flano P, Ortigosa L, White S, González C, Martí C. 1996. Land-use changes and sustainable development in mountain areas: A case study in the Spanish Pyrenees. Landsc Ecol 11(5): 267-277. doi:10.1007/ BF02059854.

Giorgi F, Lionello P. 2008. Climate change projections for the Mediterranean region. Global Planet Change 63(2-3): 90-104. doi:10.1016/j.gloplacha.2007.09.005.

Grisebach ARH. 1838. Über den Einfluss des Klimas auf die Begränzung der naturlichen Floren [On the influence of climate on the boundary of the natural flora]. Linnaea 12 : 159-200.

Houghton RA. 1994. The worldwide extent of land-use change. Bioscience 44(5): 305-313. doi:10.2307/1312380.
Iovino F. 1998. La selvicoltura in Calabria [Silviculture in Calabria]. In: AttiSecondo CongressoNazionale di Selvicoltura. Firenze: AccademiaItaliana di ScienzeForestali. pp. 219240.

Iovino F, Menguzzato G. 1991. Inquadramento fitoclimatico della Campania [The Phytoclimate of Campania]. Pubblicazione 6. Cosenza: CNR, Istituto di Ecologia e idrologia forestale. pp. 1-93.

Kaniewski D, De Laet V, Paulissen E, Waelkens M. 2007. Longterm effects of human impact on mountainous ecosystems, western Taurus Mountains, Turkey. J Biogeogr 34(11): 1975-1997. doi:10.1111/j.1365-2699.2007.01753.x.

Kendall MG. 1962. Rank correlation methods. New York: Hafner Publishing Company.

Klein tank AMG, Können GP. 2003. Trends in indices of daily temperature and precipitation extremes in Europe, 1946-99. J Climate 16(22): 3665-3680. doi:10.1175/1520-0442(2003) $016<3665::$ TIIODT $>2.0$.CO;2.

Kutiel H, Maheras P, Guika S. 1996. Circulation and extreme rainfall conditions in the eastern Mediterranean during the last century. Int J Climatol 16(1): 73-92. doi:10.1002/(SICI) 1097-0088(199601)16:1<73::AID-JOC997>3.0.CO;2-G

Lambin EF, Geist HJ, Lepers E. 2003. Dynamics of land-use and land-cover change in tropical regions. Annu Rev Environ Res 28(1): 205-241. doi:10.1146/annurev.energy.28.050302. 105459.

Lepers E, Lambin EF, Janetos AC, DeFries R, Achard F, Ramankutty N, Scholes RJ. 2005. A synthesis of information on rapid land-cover change for the period 1981-2000. BioScience 55(2): 115-124. doi:10.1641/0006-3568(2005) 055[0115:ASOIOR]2.0.CO;2.

Lionello P, Malanotte-Rizzoli P, Boscolo R. 2006. The Mediterranean climate: An overview of the main characteristics and issues. In: Lionello P, Malanotte-Rizzoli P, Boscolo R, editors. Mediterranean climate variability. Amsterdam: Elsevier. pp. $1-26$.

MacDonald D, Crabtree JR, Wiesinger G, Dax T, Stamou N, Fleury P, Gutierrez Lazpita J, Gibon A. 2000. Agricultural abandonment in mountain areas of Europe: Environmental consequences and policy response. J Environ Manage 59(1): 47-69. doi:10.1006/jema.1999.0335.

Mann HB. 1945. Nonparametric tests against trend. Econometrica 13(3): 245-259. doi:10.2307/1907187.

Marchetti M, Lasserre B, Pazzagli R, Sallustio L. 2014. Spazio rurale e urbanizzazione:analisi di un cambiamento [Rural areas and urbanization: analysis of a change]. Scienze del territorio 2 : $239-248$.

Montanari A, Rosso R, Taqqu MS. 1996. Some long-run properties of rainfall records in Italy. J Geophys Res 101: $431-438$.

Montero De Burgos JL, Gonzalez Rebollar JL. 1974. Diagramas bioclimaticos. Madrid: ICONA.

Ojima DS, Galvin KA, Turner, BL, II. 1994. The global impact of land-use change. Bioscience 44(5): 300-304. doi:10.2307/ 1312379.

Palmieri S, Siani AM, D’Agostino A. 1991. Climate fluctuations and trends in Italy within the last hundred years. Annales Geophysicae 9: 769-776.

Pavari A. 1916. Studio preliminare sulla coltura di specie forestali esotiche in Italia [A preliminary analysis of the exotic forest species in Italy]. Prima parte (generale). Annali del Regio Istituto Superiore Nazionale Forestale 1: 7-221.

Pellicone G, Caloiero T, Coletta V, Veltri A. 2014. Phytoclimatic map of Calabria (southern Italy). J Maps 10(1): 109-113. doi:10.1080/17445647.2013.860884.

Piccarreta M, Capolongo D, Boenzi F. 2004. Trend analysis of precipitation and drought in Basilicata from 1923 to 2000 
within a Southern Italy context. Int J Climatol 24(7): 907-922. doi:10.1002/joc. 1038 .

Piervitali E, Colacino M, Conte M. 1998. Rainfall over the central-western Mediterranean basin in the period 19511995. Part I: Precipitation trends. Nuovo Cimento 21: 331-344.

Piovesan G, Alessandrini A, Baliva M, Chiti T, D’Andrea E, De Cinti B, et al. 2010. Structural patterns, growth processes, carbon stocks in an Italian network of old-growth beech forests. Ital J For Mountain Environ 65: 557-590.

Prentice KC. 1990. Bioclimatic distribution of vegetation for general circulation model studies. J Geophys Res 95(D8): 11811-11830. doi:10.1029/JD095iD08p11811.

Quézel P, Médail F. 2002. Réponses de l'élément végétal (flore et végétation du basin méditerranéen) à d'éventuelles modifications climatiques [Responses of plant elements (flora and vegetation of the Mediterranean basin) to possible climate changes]. In: Changement climatique, fantasme ou réalité? Actes des tables rondes, 15 mai 2001. Montpellier: EID Méditerranée, EDEN, ADEGE \& IRD. pp. 39-45.

Regione Calabria. 2007. Rapporto sullo Stato dell'Ambiente della Calabria [Report on the environmental conditions of the Calabria Region]. Available: http://www.regione.calabria.it/ ambiente/allegati/rapportoambiente/index.html

Río S, Herrero L, Fraile R, Penas AP. 2011. Spatial distribution of recent rainfall trends in Spain (1961-2006). Int J Climatol 31(5): 656-667. doi:10.1002/joc.2111.

Rivas-Martınez S. 1993. Bases para una nueva clasificacion bioclimatica de la Tierra [Bases for a new bioclimatic classification of the Earth]. Folia Geobotanica Matritensis 10: $1-23$.

Rivas-Martinez S. 1996. Bioclimatic map of Europe. In: RivasMartinez S, editor. Geobotanica y climatologia. Granada: Universidad de Granada. pp. 25-98.

Samui T, Sitharam R, Ferrari E, Mancini M. 2011b. Machine learning modelling for predicting soil liquefaction susceptibility. Nat Hazard Earh Sys 11(1): 1-9. doi:10.5194/nhess-11$1-2011$.

Santos CP. 2000. Succession of breeding bird communities after the abandonment of agricultural fields in southeast Portugal. Ardeola 47: 171-181.
Sirangelo B, Caloiero T, Coscarelli R, Ferrari E. 2015. A stochastic model for the analysis of the temporal change of dry spells. Stoch Env Res Risk 29(1): 143-155. doi:10.1007/s00477-0140904-5.

Terzi M, Tomaselli V, Perrino P. 2006. Fitoclima della Sicilia sudorientale [The Phytoclimate of south-eastern Sicily]. Arch Geobot 8: 15-33.

Thornthwaite CW, Mather JR. 1957. Instructions and tables for computing potential evapotranspiration and the water balance. In: Laboratory of Climatology Vol. 10. Centerton, NJ: Drexel Institute of Climatology.

Tuhkanen S. 1980. Climatic parameters and indices in plant geography. Vol. 67, Acta Phytogeographica Suecica. Stockholm: Almqvist \& Wiksell International.

Ulbrich U, May W, Li L, Lionello P, Pinto JG, Somot S. 2006. The Mediterranean climate change under global warming. In: Lionello P, Malanotte-Rizzoli P, Boscolo R, editors. Mediterranean climate variability. Amsterdam: Elsevier. pp. 398-415.

Venanzoni R, Pignattelli S, Fornaciari M. 1996. La classificazione fitoclimatica dell'Umbria: Approcci e applicazioni [The Phytoclimate of Umbria: Methodologies and applications]. Annali Facoltà di Agraria Università di Perugia L: 507-523.

Vincent LA, Peterson TC, Barros VR, Marino MB, Rusticucci M, Carrasco G, et al. 2005. Observed trends in indices of daily temperature extremes in South America 1960-2000. J Climate 18(23): 5011-5023. doi:10.1175/JCLI3589.1.

Von Humboldt A, Bonpland A. 1807. Essay on the Geography of Plants. Chicago: University of Chicago Press.

Vose RS, Easterling DR, Gleason B. 2004. Maximum and minimum temperature trends for the globe: An update through 2005. Geophys Res Lett 32: L23824.

Walter H. 1985. Vegetation of the Earth and ecological systems of the geo-biosphere. New York: Springer, Verlag.

Woodward FI. 1987. Climate and plant distribution. Cambridge: Cambridge University Press.

Xoplaki E, Luterbacher J, González-Rouco JF. 2006. Mediterranean summer temperature and winter precipitation, large-scale dynamics, trends. Nuovo Cimento 29: 45-54. 